\title{
Millet derived flavonoids as potential SARS-CoV-2 main protease inhibitors: A computational approach
}

\author{
Abhisek Mishra ${ }^{1}$, Sobha Chnadra Rath ${ }^{2}$, Iswar Baitharu ${ }^{3}$, Bhawani Prasad Bag ${ }^{2 *}$ \\ ${ }^{I}$ Nabakrushna Choudhury Centre for Development Studies, Bhubaneswar, India \\ ${ }^{2}$ Department of Biotechnology and Bioinformatics, Sambalpur University, Jyoti Vihar 768019, India. \\ ${ }^{3}$ Department of Environmental Sciences, Sambalpur University, Jyoti Vihar 768019, India. \\ *Corresponding author: bpbag@ suniv.ac.in, ORCID ID: 0000-0002-8085-3497
}

\section{Graphical abstract}

\section{Abstract}

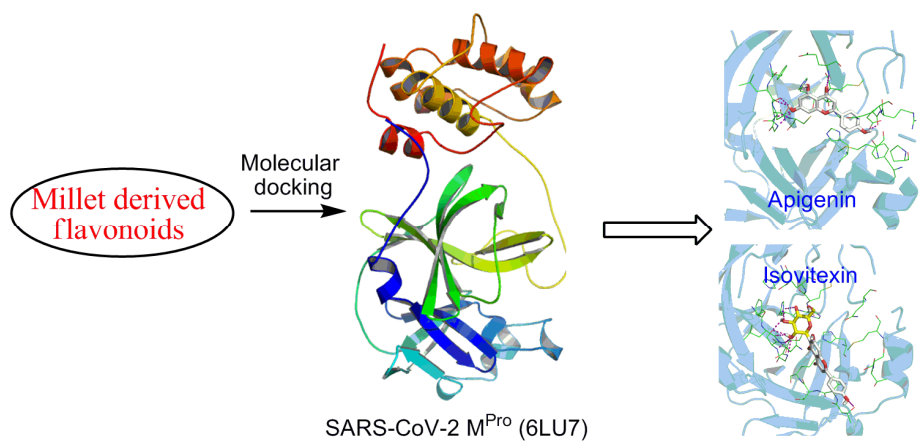

The on-going pandemic COVID-19 has emerged as a major health threat across the globe. At present, antiviral drug discoveries are of great importance in combating the pandemic. Millets are known to contain numerous flavonoids with potential anti-viral properties. However, their anti-viral efficacy against SARS-CoV-2 is yet to be studied. The study uses the SARS-CoV-2 main protease $\left(\mathrm{M}^{\mathrm{pro}}\right)$ as the potential anti-viral drug target and docks with eleven millet derived flavonoids taking HIV protease inhibiting drugs nelfinavir and saquinavir as control. AutoDock Vina was used for assessing the binding affinities and strength of bindings of flavonoids present in millet with the target protein $\mathrm{M}^{\text {pro }}$. Further, the drug-likeness and pharmacokinetics properties of these flavonoids were also analyzed using admetSAR. The ADMET analysis showed that isoorientin, orientin, vitexin, meletin, catechin, and myricetin possess potential mutagenic property while daidzein could have a negative effect on reproductive system making these compounds as poor candidates for drug development against SARS-CoV-2. Based on the docking result on high binding affinities and positive ADMET properties, the present study infers that apigenin may be considered as a potential inhibitor of SARS-CoV-2 $\mathrm{M}^{\text {pro }}$ and may be further investigated to test its anti-viral activities using in-vitro and in-vivo study.

Keywords: Millets; Flavonoids; Nutraceuticals; SARS-CoV-2 M ${ }^{\text {pro; }}$ Molecular docking; Antiviral agents 


\section{Introduction}

Infectious diseases in general and respiratory tract infection and diarrhoeal diseases in particular are one of the leading causes of mortality and morbidity across the world [1]. The on-going pandemic of coronavirus disease 2019 (COVID-19) is linked with respiratory illness caused by SARS-CoV-2 virus and was reported in December 2019 [2]. The World Health Organization reports 9,129,146 confirmed cases resulted in 473,797 deaths with a fatality rate of $5.18 \%$, across the globe (as on $25^{\text {th }}$ June 2020). Coronaviruses belong to family Coronaviridae [3] and are enveloped, large, and contain a single-stranded RNA genome that primarily causes enzootic infections in birds and mammals. The SARS-CoV-2 belongs to $\beta$ coronavirus group [4]. The incubation period ranges from 2 days to 14 days with the symptoms of cough, fatigue, myalgia, dyspnoea, and diarrhoea [5]. The corona viral genome mainly encodes four important structural proteins, viz., spike protein, nucleocapsid protein, membrane protein, and envelope protein. Among these, the entry of the virus into the host cells is mediated through spike proteins $[4,6]$. After entering into host cells, the viral genome gets translated and produces two large precursor polyproteins. Further, these polyproteins are cleaved into 16 mature non-structural proteins mediated by papain-like protease $\left(\mathrm{PL}^{\mathrm{pro}}\right)$ and main protease or 3C-like protease $\left(\mathrm{M}^{\mathrm{pro}} / \mathrm{CL}^{\mathrm{pro}}\right)$. Moreover, many of the non-structural proteins play important roles in the replication of the viral genome and their transcription [7].

Presently, the non-availability of vaccine or antiviral drugs has doubled the threat making the situation highly troublesome [8]. To reduce the complicacies, various preventive as well as supportive therapies are being implemented [8,9]. To develop a therapeutic agent against SARS-CoV-2, screening the existing natural inhibitors is highly important. The present study aims to use the main protease $\mathrm{M}^{\text {pro }}$ as the potential anti-viral drug target due to the following reasons. First, $\mathrm{M}^{\text {pro }}$ of coronavirus has been studied extensively in the drug discovery $[8,2,10]$. Therefore, the structural as well as functional information related to this protein is available. Further, it has acted as a proven drug target for SARS-CoV [2], which shares the highest similarity with SARS-CoV-2, and also there is a prevalence of high sequence identity with the structural similarity of $\mathrm{M}^{\text {pro }}$ from SARS-CoV-2 with SARS-CoV $\mathrm{M}^{\text {pro }}$ as shown in Figure 1 . Second, $3 \mathrm{CL}^{\text {pro }}$ plays a key role in its self-maturation and the maturation of replicase enzymes and is known to inhibit the viral replication [11].

Literature on the use of natural products and medicinal plants as therapeutic against metabolic as well as infective diseases is more prevalent due to their minimal side effects $[2,10,12]$. In the context of the multiplication of viruses in the host body, it is evident that the 
multiplication rate is known to be high when the immune system of the host is weak [13]. To strengthen the immune system, consumption of nutritious food is highly encouraged as nutrition plays a crucial role in the prevention of chronic diseases [14] when the essential nutrients act as nutraceuticals. The micronutrient content like minerals, vitamins, and presence of numerous secondary metabolites with strong anti-oxidant properties along with rich dietary fibre make millets an important functional food and nutraceuticals [15]. Further, millets contain several flavonoids like catechin, quercetin, luteolin, orientin, apigenin, isoorientin, vitexin, myricetin, isovitexin, daidzein, sponarin, violanthin, lucenin-1, and tricin; some of which have been demonstrated as effective anti-viral agents against swine fever virus and rotavirus [1621]. However, the effect of these flavonoids on SARS-CoV-2 is scantly investigated. Thus, to breeze the conspicuous gap, this study attempts to explore the effectiveness of these flavonoids against SARS-CoV-2 using computational analysis.

(a)

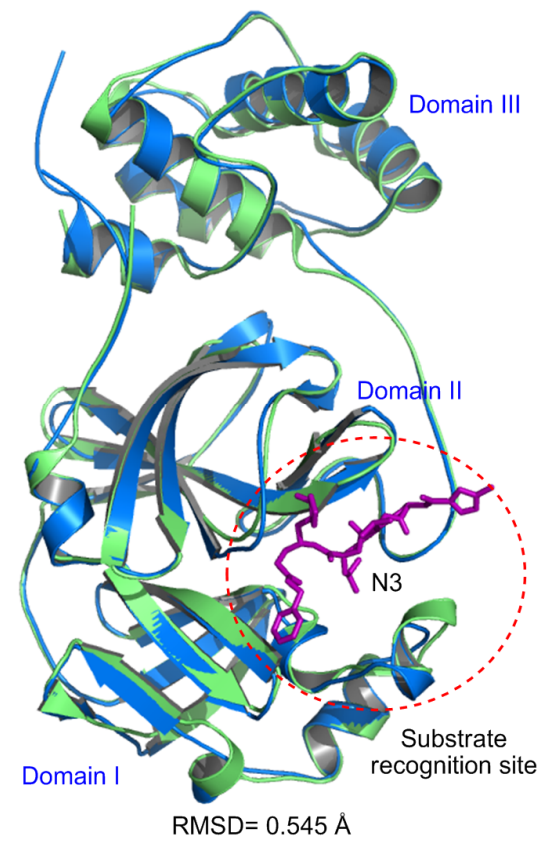

(b)

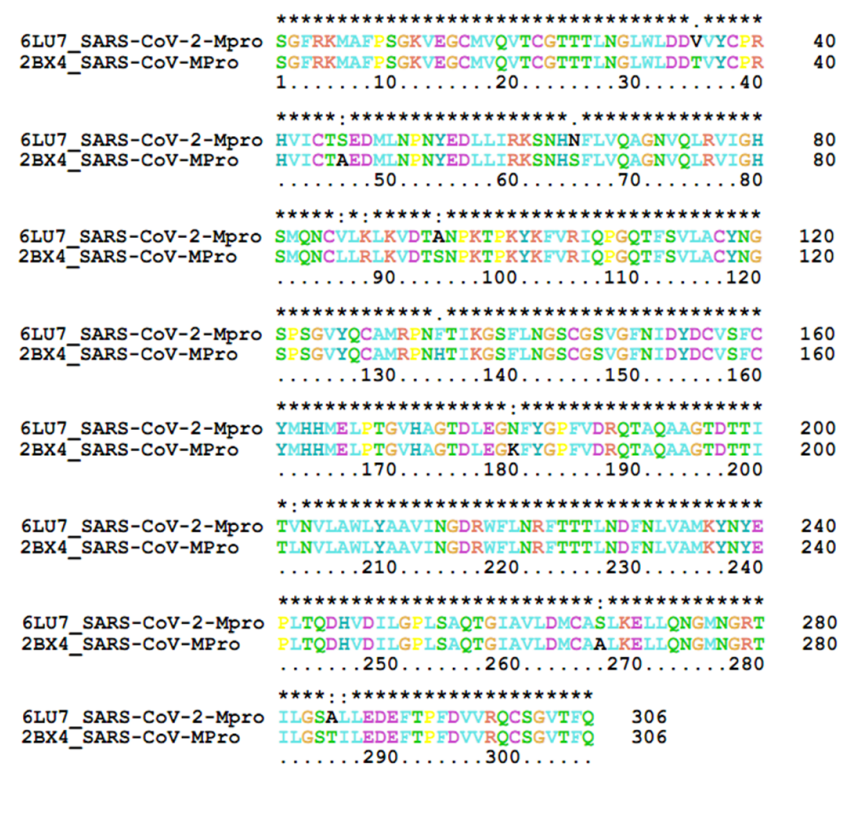

Figure 1: Schematic representation of main protease monomer (a) Superimposed structure of

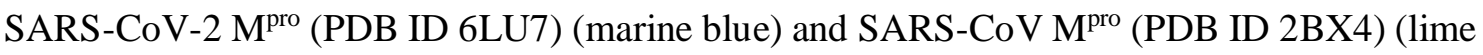
green). SARS-CoV-2 $\mathrm{M}^{\text {pro }}$ comprises domain-I (residues 8-101), domain-II (residues 102-184), and domain-III (residues 201-303). Inhibitor N3 is in purple colour. (b) Sequence alignment of SARS-CoV-2 $\mathrm{M}^{\text {pro }}$ and SARS-CoV $\mathrm{M}^{\text {pro }}$

\section{Materials and methods}

\subsection{Molecular docking}

Docking studies of different millet derived flavonoids with the SARS-CoV-2 main protease $\left(\mathrm{M}^{\mathrm{pro}}\right)$ were carried out using AutoDock Vina [22]. HIV protease inhibiting drugs 
nelfinavir and saquinavir were used as control. Three-dimensional structures of the ligands as well as the reference drugs were downloaded from the ZINC database (https://zinc.docking.org/) [23] in SDF format. Subsequently, all compounds were optimized with the Merck Molecular Force Field (MMFF94) [24] using PyRx [25]. The crystallographic structure of the SARS-CoV-2 M $\mathrm{M}^{\text {pro }}$ with inhibitor N3 (PDB ID: 6LU7) [26] was retrieved from the protein data bank (http://www.rcsb.org/) [27] and processed before docking. During the process, polar hydrogen atoms and Kollman charges were added to the protein molecule. The active site residues were identified using ArgusLab (www.arguslab.com/arguslab.html). A

search space around the active site was set to 25,33 , and $33 \AA$ for $\mathrm{x}, \mathrm{y}$, and $\mathrm{z}$ dimensions, respectively, and centered at $-15.52,-29.86$, and $6.75 \AA$ A based on N3 binding site. The grid spacing was set to $1 \AA$. To validate the docking protocol, first, inhibitor N3 was removed from the binding site of the main protease and re-docked using the same parameters and search space. The minimum energy conformation for each ligand was ranked according to the empirical scoring function. All protein-ligand complexes were analyzed and visualized with PyMol molecular graphics system (https://pymol.org/) [28]. LigPlot+ was used to infer interactions between the ligands and the protein [29].

\subsection{Drug-likeness and toxicity analysis}

Molinspiration property engine v.2018.10 (https://www.molinspiration.com/cgibin/properties) was used to predict properties like molecular weight, topological polar surface area (TPSA), LogP, hydrogen bond acceptors, and hydrogen bond donors to evaluate druglikeness. ADMET (absorption, distribution, metabolism, excretion, and toxicity) properties were calculated through admetSAR [30] and DataWarrior program [31]. Descriptors such as blood-brain barrier (BBB), human intestine absorption (HIA), cytochrome 450 inhibitor, aqueous solubility, mutagenicity, tumorigenicity, carcinogenicity, reproductive effect, and irritability were analysed for assessing ADMET properties. The above properties are essential in ascertaining the effect of the inhibitor to the human body, which affects and determines the performance of the ligand [32].

\section{Results and discussion}

\subsection{Visualisation and analysis of docked structures}

$\mathrm{M}^{\text {pro }}$ of SARS-CoV-2 was the preferred target because of its involvement in the viral replication and transcription. The substrate-binding site is located between domain-I and domain-II. The key residues involved in the substrate-binding are Thr24, Thr25, Thr26, His41, 
Phe140, Leu141, Asn142, Gly143, Ser144, Cys145, His163, Met165, Glu166, His172, Asp187. Several flavonoids from millet were docked against the target to analyse the inhibitory activities and the molecular interactions within the binding site. The molecular docking results revealed that the identified millet flavonoids showed good binding affinities towards SARSCoV-2 $\mathrm{M}^{\text {pro }}$ ranging from -8.1 to $-7.2 \mathrm{kcal} / \mathrm{mol}$. Saquinavir and nelfinavir (reference drugs) showed binding affinity of -8.5 and $-7.7 \mathrm{kcal} / \mathrm{mol}$ respectively. When compared with inhibitor $\mathrm{N} 3(-7.7 \mathrm{kcal} / \mathrm{mol})$, out of all flavonoids (considered in the study), isovitexin, isoorientin, apigenin, and orientin exhibited greater binding affinities. Among these, isovitexin (apigenin6-C-glucoside) showed the highest binding affinity of $-8.1 \mathrm{kcal} / \mathrm{mol}$ and formed ten hydrogen bonds with Thr24, Leu141, Gly143, Ser144, Cys145, and His163; whereas, Thr25, Thr26, Phe140, Asn142, Met165, and Glu166 were observed to form hydrophobic interactions (Figure 2a).

(a)

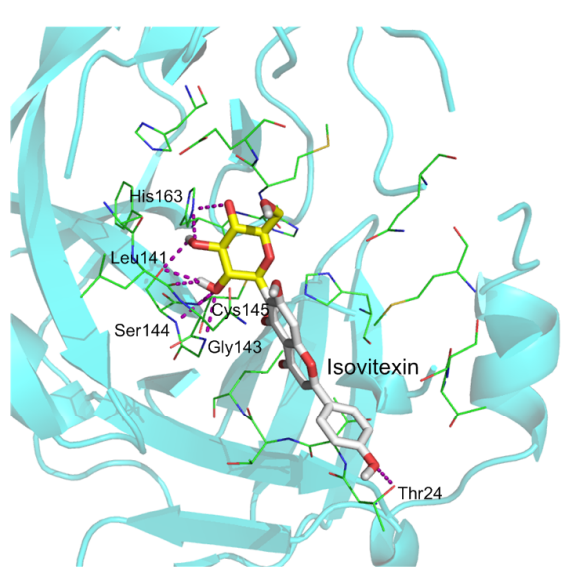

(b)

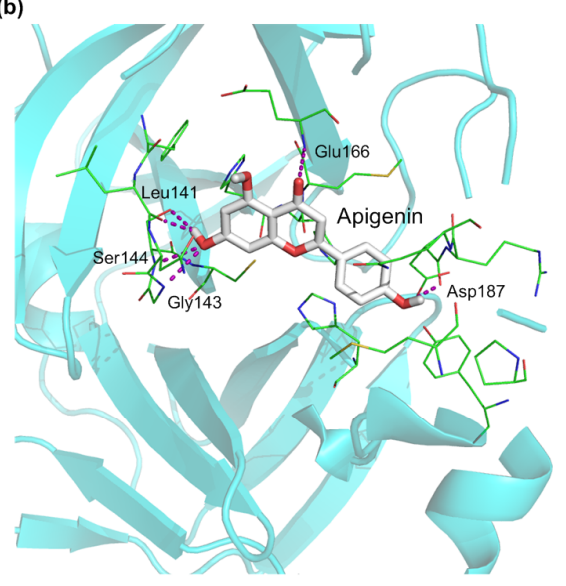

(c)

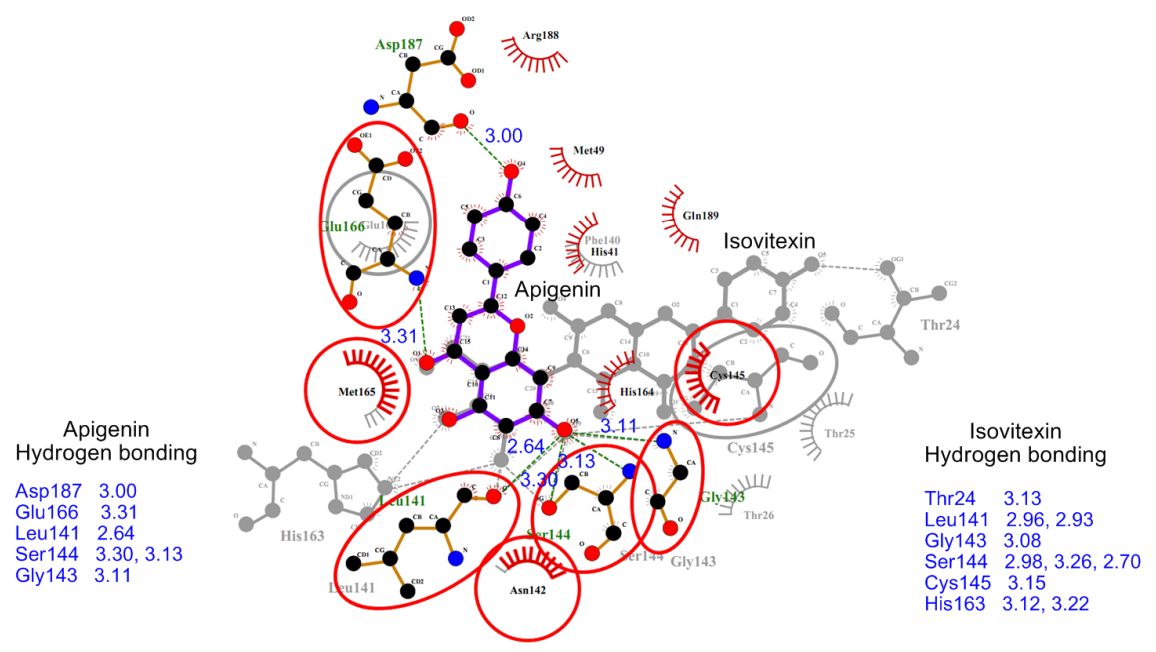

Figure 2: Pictorial representation of selected compounds from millet docked to the active site

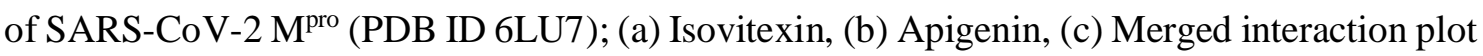
of isovitexin and apigenin. 
The binding affinity of isoorientin was found to be $-7.9 \mathrm{Kcal} / \mathrm{mol}$ forming nine hydrogen bonds with Thr24, Thr45, Gly143, Cys145, Ser144, Leu141, and His163. Both apigenin and orientin showed the same binding energies of $-7.8 \mathrm{kcal} / \mathrm{mol}$ (third highest) but they differed in forming their hydrogen bonds and interactions. Apigenin formed six hydrogen bonds with Asp187, Glu166, Leu141, Sr144, Gly143 showing hydrophobic interactions of Met165, Asn142, Cys145, His164, His41, Gln189, Met49, Arg188 (Figure 2b); whereas, orientin formed eight hydrogen bonds with Phe140, Gln189, Thr190, Gln192, Arg188, and Cys145 showing hydrophobic interactions of Glu166, Pro168, Met165, His164, His41. The comparative interaction plot of isovitexin and apigenin with $\mathrm{M}^{\text {pro }}$ shows better result for isovitexin (Figure 2c). The binding affinities and the molecular interactions of all the molecules with SARS-CoV-2 $\mathrm{M}^{\text {pro }}$ are depicted in Table 1.

\subsection{Drug-likeness and ADMET analysis}

In the drug development process, Lipinski rule of five and ADMET analysis plays a significant role as it explains the drug likeliness nature of the compounds [18]. As mentioned, blood-brain barrier, human intestine absorption, cytochrome 450 inhibitor, aqueous solubility, mutagenicity, tumorigenicity, carcinogencity, reproductive effect, and irritability properties of all the ligands were analyzed. Analysis of molecular properties showed that all compounds except isoorientin and orientin obeys Lipinski rule of five (Table 2). The ADMET result demonstrates that all the compounds analysed cannot cross BBB and has higher positive HIA. None of the compounds were found to be an inhibitor of cytochrome 450. However, the ADMET analysis indicates that flavonoids like isoorientin, orientin, vitexin, meletin, catechin, and myricetin were having mutagenic property and daidzein showed negative effect on the reproductive process. Hence, these compounds are poor candidates for drug development against SARS-CoV-2. Although luteolin and tricin do not show mutagenicity, tumorigenicity, negative reproductive effect, and irritability properties, these compounds are not suitable for anti-viral drug development owing to their poor binding energies with $\mathrm{M}^{\text {pro }}$ (Table 3). Thus, in a nutshell, it is articulated from the ADMET result that only two compounds (isovitexin and apigenin) may be considered further as a drug candidate against SARS-CoV-2. Moreover, out of the two compounds, the TPSA value of isovitexin was found to be above 140, which may affect the membrane permeability of the molecule [18]. Thus, apigenin was the only compound fulfilling all ADMET properties and may be used as an anti-viral agent against SARS-CoV-2. 
Table 1: Binding energy of millet derived flavonoid against SARS-CoV-2 $\mathrm{M}^{\text {Pro }}$

\begin{tabular}{|c|c|c|c|c|c|}
\hline Compound & $\begin{array}{c}\text { Binding affinity (kcal/mol) } \\
\text { with SARS-CoV-2 MPro }\end{array}$ & $\begin{array}{l}\text { Residues involved } \\
\text { in H-bond }\end{array}$ & $\begin{array}{l}\text { H-bond distance } \\
(\AA)\end{array}$ & $\begin{array}{l}\text { Hydrophobic } \\
\text { interactions }\end{array}$ & Phytochemical structure \\
\hline Isovitexin & -8.1 & $\begin{array}{c}\text { Thr24 } \\
\text { Leu141 } \\
\text { Gly143 } \\
\text { Ser144 } \\
\text { Cys145 } \\
\text { His163 }\end{array}$ & $\begin{array}{c}3.13 \\
2.96,2.93 \\
3.08 \\
2.98,3.26,2.70 \\
3.15 \\
3.12,3.22\end{array}$ & $\begin{array}{c}\text { Thr25, Thr26, } \\
\text { Phe140, Asn142, } \\
\text { Met165, Glu166 }\end{array}$ & \\
\hline Isoorientin & -7.9 & $\begin{array}{c}\text { Thr24 } \\
\text { Thr45 } \\
\text { Gly143 } \\
\text { Cys145 } \\
\text { Ser144 } \\
\text { Leu141 } \\
\text { His163 }\end{array}$ & $\begin{array}{c}3.30,2.86 \\
3.27 \\
2.94 \\
3.31 \\
3.05 \\
2.79,2.52 \\
3.13\end{array}$ & $\begin{array}{l}\text { Thr25, Leu27, } \\
\text { Met165, Phe140, } \\
\text { Asn142, Glu166 }\end{array}$ & \\
\hline Apigenin & -7.8 & $\begin{array}{l}\text { Asp187 } \\
\text { Glu166 } \\
\text { Leu141 } \\
\text { Ser144 } \\
\text { Gly143 }\end{array}$ & $\begin{array}{c}3.00 \\
3.31 \\
2.64 \\
3.30,3.13 \\
3.11\end{array}$ & $\begin{array}{c}\text { Met165, Asn142, } \\
\text { Cys145, His164, } \\
\text { His41, Gln189, } \\
\text { Met49, Arg188 }\end{array}$ & \\
\hline Orientin & -7.8 & $\begin{array}{l}\text { Phe140 } \\
\text { Gln189 } \\
\text { Thr190 } \\
\text { Gln192 } \\
\text { Arg188 } \\
\text { Cys145 }\end{array}$ & $\begin{array}{c}2.97 \\
3.14 \\
3.21,3.23,2.58 \\
2.74 \\
2.76 \\
3.26\end{array}$ & $\begin{array}{c}\text { Glu166, Pro168, } \\
\text { Met165, His164, } \\
\text { His41 }\end{array}$ & \\
\hline
\end{tabular}




\begin{tabular}{|c|c|c|c|c|}
\hline Vitexin & -7.6 & $\begin{array}{c}\text { Thr26 } \\
\text { His163 } \\
\text { Ser144 } \\
\text { Leu141 } \\
\text { Phe140 } \\
\text { Glu166 } \\
\text { Asn142 }\end{array}$ & $\begin{array}{l}3.17 \\
3.03 \\
3.06 \\
3.17 \\
3.22 \\
3.12 \\
2.75 \\
\end{array}$ & $\begin{array}{c}\text { Gln189, Met165, } \\
\text { His41, Gly143, } \\
\text { His164 }\end{array}$ \\
\hline $\begin{array}{c}\text { Meletin } \\
\text { (Quercetin) }\end{array}$ & -7.5 & $\begin{array}{l}\text { Gln189 } \\
\text { Ser144 } \\
\text { Leu141 } \\
\text { His163 }\end{array}$ & $\begin{array}{l}2.86 \\
2.81 \\
2.81 \\
3.20\end{array}$ & $\begin{array}{c}\text { His41, Met49, } \\
\text { Asp187, Glu166, } \\
\text { Phe140, Met165, } \\
\text { Cys145 }\end{array}$ \\
\hline Luteolin & -7.4 & $\begin{array}{l}\text { Thr190 } \\
\text { Asn142 } \\
\text { Arg188 } \\
\text { Gln192 }\end{array}$ & $\begin{array}{c}2.77,2.83,3.32 \\
2.95 \\
2.77 \\
3.06\end{array}$ & $\begin{array}{c}\text { Glu166, Gln189, } \\
\text { His41, His164, } \\
\text { Cys145, Met165 }\end{array}$ \\
\hline Tricin & -7.4 & $\begin{array}{l}\text { Gly143 } \\
\text { His163 } \\
\text { Cys145 } \\
\text { Ser144 } \\
\text { Leu141 }\end{array}$ & $\begin{array}{c}3.16 \\
2.94 \\
3.29 \\
2.96,3.15 \\
2.76\end{array}$ & $\begin{array}{l}\text { His172, Phe140, } \\
\text { Met165, Glu166, } \\
\text { Arg188, Gln189, } \\
\text { Asn142 }\end{array}$ \\
\hline Catechin & -7.3 & $\begin{array}{l}\text { Ser144 } \\
\text { Leu141 } \\
\text { Gln189 }\end{array}$ & $\begin{array}{l}2.87 \\
2.95 \\
2.74\end{array}$ & $\begin{array}{c}\text { Arg188, Met165, } \\
\text { His164, Cys145, } \\
\text { His163, Phe140, } \\
\text { Glu166 }\end{array}$ \\
\hline
\end{tabular}




\begin{tabular}{|c|c|c|c|c|c|}
\hline Myricetin & -7.3 & & $\begin{array}{l}\text { Ser144 } \\
\text { Leu141 } \\
\text { His163 } \\
\text { Arg188 } \\
\text { Gly143 } \\
\text { Cys145 }\end{array}$ & $\begin{array}{c}2.82,3.14,2.96 \\
2.81,2.95 \\
2.89 \\
2.87 \\
3.20 \\
3,24\end{array}$ & $\begin{array}{c}\text { Asn142, Met165, } \\
\text { Glu166, Gln189, } \\
\text { Phe140 }\end{array}$ \\
\hline Daidzein & -7.2 & & $\begin{array}{l}\text { Phe140 } \\
\text { Asp187 }\end{array}$ & $\begin{array}{l}3.01 \\
3.06\end{array}$ & $\begin{array}{l}\text { Asn142, Leu141, } \\
\text { Gln189, Met165, } \\
\text { Arg188, His164, } \\
\text { His41, Cys145, } \\
\text { His163 }\end{array}$ \\
\hline \multicolumn{6}{|c|}{ Control (HIV protease inhibiting drugs) } \\
\hline Saquinavir & Synthetic drug & -8.5 & $\begin{array}{c}\text { Tyr54 } \\
\text { Asp187 } \\
\text { Gln189 } \\
\text { Asn142 }\end{array}$ & $\begin{array}{c}3.18 \\
3.27 \\
3.14,3.17 \\
3.16\end{array}$ & $\begin{array}{l}\text { Leu141, Glu166, } \\
\text { Met165, His41, } \\
\text { Arg188, Met49, } \\
\text { Thr26, Cys145, } \\
\text { Leu27, Thr25, } \\
\text { Gly143, Phe140 }\end{array}$ \\
\hline Nelfinavir & Synthetic drug & -7.7 & $\begin{array}{c}\text { Glu166 } \\
\text { Thr26 }\end{array}$ & $\begin{array}{l}2.80 \\
2.80\end{array}$ & $\begin{array}{l}\text { Met49, Asn142, } \\
\text { Gly143, Thr25, } \\
\text { His41, Gln189, } \\
\text { His164, Met165, } \\
\text { Arg188, Thr190 }\end{array}$ \\
\hline
\end{tabular}


Table 2: Molecular properties to predict drug likeliness of selective millet flavonoids

\begin{tabular}{|c|c|c|c|c|c|c|c|c|}
\hline Compound & ZINC ID & Mol. Weight & TPSA & $\log P$ & HB Acceptor & HB donor & No. of Violation & $\begin{array}{l}\text { admetSAR } \\
\text { prediction * }\end{array}$ \\
\hline Isovitexin & ZINC4095704 & 432.38 & 181.04 & 0.52 & 10 & 7 & 1 & In domain \\
\hline Isoorientin & ZINC4349262 & 448.38 & 201.27 & 0.03 & 11 & 8 & 2 & Warning \\
\hline Apigenin & ZINC3871576 & 270.24 & 90.89 & 2.46 & 5 & 3 & 0 & In domain \\
\hline Orientin & ZINC4098560 & 448.38 & 201.27 & 0.03 & 11 & 8 & 2 & Warning \\
\hline Vitexin & ZINC4245684 & 432.38 & 181.04 & 0.52 & 10 & 7 & 1 & In domain \\
\hline Meletin & ZINC3869685 & 302.24 & 131.35 & 1.68 & 7 & 5 & 0 & In domain \\
\hline Luteolin & ZINC18185774 & 286.24 & 111.12 & 1.97 & 6 & 4 & 0 & In domain \\
\hline Tricin & ZINC5998961 & 330.29 & 109.36 & 2.30 & 7 & 3 & 0 & In domain \\
\hline Catechin & ZINC119978 & 290.27 & 110.37 & 1.37 & 6 & 5 & 0 & In domain \\
\hline Myricetin & ZINC3874317 & 318.24 & 151.58 & 1.39 & 8 & 6 & 1 & In domain \\
\hline Daidzein & ZINC18847034 & 254.24 & 70.67 & 2.56 & 4 & 2 & 0 & In domain \\
\hline \multicolumn{9}{|c|}{ Control (HIV protease inhibiting drugs) } \\
\hline Saquinavir & ZINC3914596 & 670.86 & 166.75 & 4.26 & 7 & 5 & 1 & In domain \\
\hline Nelfinavir & ZINC3833846 & 567.80 & 101.89 & 5.47 & 6 & 4 & 1 & In domain \\
\hline
\end{tabular}

TPSA- Topological polar surface area, HB acceptor- Hydrogen bond acceptor, HB donor- Hydrogen bond donor.

* admetSAR prediction description: http://lmmd.ecust.edu.cn/admetsar2/about/ad 
Table 3: Pharmacokinetics and toxicity assessment of millet flavonoids

\begin{tabular}{|c|c|c|c|c|c|c|c|c|c|}
\hline Compound & ZINC ID & BBB & HIA & $\begin{array}{l}\text { CYP2D6 } \\
\text { inhibitor }\end{array}$ & $\begin{array}{l}\text { Aqueous } \\
\text { solubility }\end{array}$ & $\begin{array}{c}\text { Ames } \\
\text { mutagenesis }\end{array}$ & Tumorigenic & $\begin{array}{c}\text { Reproductive } \\
\text { effects }\end{array}$ & Irritant \\
\hline Isovitexin & ZINC4095704 & - & + & - & -2.398 & - & None & None & None \\
\hline Isoorientin & ZINC4349262 & - & + & - & -2.398 & + & None & None & None \\
\hline Apigenin & ZINC3871576 & - & + & - & -2.777 & - & None & None & None \\
\hline Orientin & ZINC4098560 & - & + & - & -2.398 & + & None & None & None \\
\hline Vitexin & ZINC4245684 & - & + & - & -2.398 & + & None & None & None \\
\hline Meletin & ZINC3869685 & - & + & - & -2.999 & + & High & None & None \\
\hline Luteolin & ZINC18185774 & - & + & - & -2.999 & - & None & None & None \\
\hline Tricin & ZINC5998961 & - & + & - & -3.289 & - & None & None & None \\
\hline Catechin & ZINC119978 & - & + & - & -3.101 & + & None & None & None \\
\hline Myricetin & ZINC3874317 & - & + & - & -2.999 & + & None & None & None \\
\hline Daidzein & ZINC18847034 & - & + & - & -3.205 & - & None & High & None \\
\hline \multicolumn{10}{|c|}{ Control (HIV protease inhibiting drugs) } \\
\hline Saquinavir & ZINC3914596 & + & + & - & -3.225 & - & None & None & None \\
\hline Nelfinavir & ZINC3833846 & - & + & - & -3.499 & - & None & None & None \\
\hline
\end{tabular}

BBB: Blood-brain barrier, HIA: Human intestine absorption, CYP2D6: Cytochrome P450 2D6. 


\section{Conclusion}

The present study investigated the potential inhibitors of SARS-CoV-2 considering millet derived flavonoids. The $\mathrm{M}^{\text {pro }}$ of SARS-CoV-2 was docked with eleven millet derived flavonoids, i.e., isovitexin, isoorientin, apigenin, orientin, vitexin, meletin, luteolin, and tricin, catechin, myricetin, and daidzein along with two reference drugs. Based on the high binding affinities and positive ADMET properties, the present study infers that apigenin may be considered as a potential inhibitor of SARS-CoV-2 $\mathrm{M}^{\text {pro }}$. Intake of millets should be recommended to boost the immune system which can eventually effective towards covid-19. However, further extensive in-vitro and in-vivo studies need to be conducted to verify the antiviral activity of apigenin.

\section{Conflict of interest}

There is no conflict of interest.

\section{Acknowledgment}

The authors are very much thankful to the Department of Biotechnology and Bioinformatics, Sambalpur University for providing the computational facilities. The authors are also grateful to Prof. Srijit Mishra (Director, Nabakrushna Chodhury Centre of Development Studies) and Dr. Byomakesh Debata (Birla Institute of Technology and Science, Pilani) for their valuable suggestions in fine-tuning the manuscript.

\section{References}

1. Reygaert WC (2018) Green tea catechins: Their use in treating and preventing infectious diseases. BioMed Res Int 2018

2. ul Qamar MT, Alqahtani SM, Alamri MA, Chen L-L (2020) Structural basis of SARS-CoV2 3CLpro and anti-COVID-19 drug discovery from medicinal plants. J Pharm Anal

3. Enjuanes L, Almazán F, Sola I, Zuñiga S (2006) Biochemical aspects of coronavirus replication and virus-host interaction. Annu Rev Microbiol 60:211-230

4. Schoeman D, Fielding BC (2019) Coronavirus envelope protein: current knowledge. Virol J 16 (1):1-22

5. Lai C-C, Shih T-P, Ko W-C, Tang H-J, Hsueh P-R (2020) Severe acute respiratory syndrome coronavirus 2 (SARS-CoV-2) and corona virus disease-2019 (COVID-19): the epidemic and the challenges. Int J Antimicrob Agents:105924

6. Li F (2013) Receptor recognition and cross-species infections of SARS coronavirus. Antiviral Res 100 (1):246-254 
7. Narayanan K, Ramirez SI, Lokugamage KG, Makino S (2015) Coronavirus nonstructural protein 1: Common and distinct functions in the regulation of host and viral gene expression. Virus Res 202:89-100

8. Joshi RS, Jagdale SS, Bansode SB, Shankar SS, Tellis MB, Pandya VK, Chugh A, Giri AP, Kulkarni MJ (2020) Discovery of potential multi-target-directed ligands by targeting hostspecific SARS-CoV-2 structurally conserved main protease. J Biomol Struct Dyn:1-16

9. Salata C, Calistri A, Parolin C, Palu G (2019) Coronaviruses: a paradigm of new emerging zoonotic diseases. Pathog Dis 77 (9):ftaa006

10. Sampangi-Ramaiah MH, Vishwakarma R, Shaanker RU (2020) Molecular docking analysis of selected natural products from plants for inhibition of SARS-CoV-2 main protease. Curr Sci 118 (7):1087-1092

11. Zhang L, Lin D, Sun X, Curth U, Drosten C, Sauerhering L, Becker S, Rox K, Hilgenfeld R (2020) Crystal structure of SARS-CoV-2 main protease provides a basis for design of improved $\alpha$-ketoamide inhibitors. Science 368 (6489):409-412

12. Khaerunnisa S, Kurniawan H, Awaluddin R, Suhartati S, Soetjipto S (2020) Potential inhibitor of COVID-19 main protease (Mpro) from several medicinal plant compounds by molecular docking study. Prepr doi10 20944:1-14

13. Regoes RR, Hamblin S, Tanaka MM (2013) Viral mutation rates: modelling the roles of within-host viral dynamics and the trade-off between replication fidelity and speed. Proc $\mathrm{R}$ Soc B: Biol Sci 280 (1750):20122047

14. Lopez-Varela S, González-Gross M, Marcos A (2002) Functional foods and the immune system: a review. Eur J Clin Nutr 56 (3):S29-S33

15. Gupta N, Srivastava A, Pandey V (2012) Biodiversity and nutraceutical quality of some indian millets. Proc Natl Acad Sci, India Sec B: Biol Sci 82 (2):265-273

16. Chandrasekara A, Shahidi F (2011) Determination of antioxidant activity in free and hydrolyzed fractions of millet grains and characterization of their phenolic profiles by HPLC-DAD-ESI-MSn. J Funct Foods 3 (3):144-158

17. Pradeep P, Sreerama YN (2017) Soluble and bound phenolics of two different millet genera and their milled fractions: Comparative evaluation of antioxidant properties and inhibitory effects on starch hydrolysing enzyme activities. J Funct Foods 35:682-693

18. Pathak RK, Gupta A, Shukla R, Baunthiyal M (2018) Identification of new drug-like compounds from millets as Xanthine oxidoreductase inhibitors for treatment of Hyperuricemia: A molecular docking and simulation study. Comput Biol Chem 76:32-41 
19. Nithiyanantham S, Kalaiselvi P, Mahomoodally MF, Zengin G, Abirami A, Srinivasan G (2019) Nutritional and functional roles of millets-A review. J Food Biochem 43 (7):e12859

20. Knipping K, Garssen J, van't Land B (2012) An evaluation of the inhibitory effects against rotavirus infection of edible plant extracts. Virol J 9 (1):1-8

21. Hakobyan A, Arabyan E, Avetisyan A, Abroyan L, Hakobyan L, Zakaryan H (2016) Apigenin inhibits African swine fever virus infection in vitro. Arch Virol 161 (12):34453453

22. Trott O, Olson AJ (2010) AutoDock Vina: improving the speed and accuracy of docking with a new scoring function, efficient optimization, and multithreading. J Comput Chem 31 (2):455-461

23. Sterling T, Irwin JJ (2015) ZINC 15-ligand discovery for everyone. J Chem Inf Model 55 (11):2324-2337

24. Halgren TA (1996) Merck molecular force field. I. Basis, form, scope, parameterization, and performance of MMFF94. J Comput Chem 17 (5 $\square 6): 490-519$

25. Dallakyan S, Olson AJ (2015) Small-molecule library screening by docking with PyRx. In: Chem Biol. Springer, pp 243-250

26. Jin Z, Du X, Xu Y, Deng Y, Liu M, Zhao Y, Zhang B, Li X, Zhang L, Peng C (2020) Structure of M pro from SARS-CoV-2 and discovery of its inhibitors. Nature:1-5

27. Berman H, Westbrook J, Feng Z, Gilliland G, Bhat T, Weissig H, Shindyalov I, Bourne P (2000) The Protein Data Bank. Nucleic Acids Res 28: 235-242.

28. DeLano WL (2002) Pymol: An open-source molecular graphics tool. CCP4 Newsletter on protein crystallogr $40(1): 82-92$

29. Laskowski RA, Swindells MB (2011) LigPlot+: multiple ligand-protein interaction diagrams for drug discovery. J Chem Inf Model 51:2778-2786

30. Yang H, Lou C, Sun L, Li J, Cai Y, Wang Z, Li W, Liu G, Tang Y (2019) admetSAR 2.0: web-service for prediction and optimization of chemical ADMET properties. Bioinformatics 35 (6):1067-1069

31. Sander T, Freyss J, von Korff M, Rufener C (2015) DataWarrior: an open-source program for chemistry aware data visualization and analysis. J Chem Inf Model 55 (2):460-473

32. Isa MA, Majumdar RS (2019) Computer-aided drug design based on comparative modeling, molecular docking and molecular dynamic simulation of Polyphosphate kinase (PPK) from Mycobacterium tuberculosis. J Proteins Proteomics 10 (1):55-68 